\title{
KONFIRMASI LIMA FAKTOR YANG BERPENGARUH TERHADAP KEMANDIRIAN PERIMENOPAUSE DALAM MEMENUHI KEBUTUHAN ACTIVITIES DAILY LIVING (ADL)
}

\author{
Confirmation of Five Factors that Affect the Independence of Perimenopause in Meeting \\ Needs Activities Daily Living (ADL)
}

\author{
Taufianie Rossita $^{1}$, Yesi Putri ${ }^{2}$, Desi Aulia Umami ${ }^{3}$ \\ 1. Universitas Dehasen Bengkulu
}

\section{Riwayat artikel}

Diajukan: September 2020

Diterima: Maret 2021.

\section{PenulisKorespondensi: \\ - Taufianie Rossita \\ - Universitas Dehasen Bengkulu \\ - taufianirossita@unived. ac.id}

\section{Kata Kunci: \\ Keluarga, Kemandirian, Lingkungan, Motivasi, Tokoh Masyarakat}

\begin{abstract}
Abstrak
Perimenopause yang mandiri menunjukan suatu keadaan dimana seseorang yang memiliki keputusan dan inisiatif untuk mengatasi masalah yang dihadapi, memiliki kepercayaan diri dalam mengerjakan tugas-tugasnya, bertanggung jawab terhadap apa yang dilakukan. Tujuan penelitian ini untuk mengetahui konfirmasi lima faktor yang berpengaruh terhadap kemandirian perimenopause dalam memenuhi kebutuhan activities daily living ( $a d l$ ). Jenis penelitian ini kuantitatif dengan desain penelitian cross sectional. Penelitian ini dilakukan pada bulan November 2017. Populasi dalam penelitian ini adalah wanita perimenopause di Wilayah Kecamatan Batununggal Bandung sebanyak 285 responden. Ukuran sampel dalam penelitian ini ditetapkan sebanyak 75 responden, teknik pengambilan sampel penelitian menggunakan purposive sampling. Pengumpulan data menggunakan kuesioner, kemudian dianalisis sampai analisis multivariat dan data disajikan dalam bentuk narasi, tabular, dan grafik/gambar. Pengaruh paling besar terhadap variabel kemandirian wanita perimenopause didapatkan berasal dari variabel fungsi keluarga sebesar $26,94 \%$, sedangkan pengaruh paling kecil berasal dari variabel lingkungan sosial sebesar $14,00 \%$. Model mampu menjelaskan variabilitas data sebesar $98,92 \%$, sedangkan $1,08 \%$ dijelaskan oleh variabel lain yang tidak dikaji dalam penelitian ini. Jika wanita perimenopause mendapatkan fungsi keluarga yang baik, maka diharapkan kemandirian wanita perimenopause pun akan baik. Diharapkan keluarga membantu wanita perimenopause memelihara kesehatan dan fungsi kehidupannya sehingga wanita perimenopause mandiri dalam memenuhi kebutuhan sehari-hari dengan mewujudkan pola hidup teratur dan seimbang.
\end{abstract}

\section{Abstract}

Independent perimenopause shows a situation in which a person who has a decision and an initiative to deal with a problem at hand, has confidence in doing his or her duties, is responsible for what is done. The purpose of this research is to know the direct and indirect influence and the magnitude of social environment, the role of community leaders, the family function and the motivation towards the independence of perimenopause in fulfilling the needs of Activities Daily Living. This research type is quantitative with cross sectional research design. This study was conducted in November 2017. The population in this study was perimenopausal women in Batununggal District of Bandung as many as 285 respondents. Sample size in this study was determined as much as 75 respondents, sampling technique research using purposive sampling. Data collection using questionnaire, then analyzed until multivariate analysis and data presented in the form of narration, tabular, and graph / picture. The greatest influence on the independence variable of perimenopausal women was derived from family function variable of $26.94 \%$, while the smallest effect came from social environment variable equal to $14.00 \%$. The model is able to explain data variability of $98.92 \%$, while $1.08 \%$ is explained by other variables that are not examined in this study. If perimenopausal women get a good family function, it is hoped the independence of perimenopausal women will be good. It is hoped that the family helps perimenopausal women to maintain their health and life function so that perimenopausal women are self-sufficient in fulfilling their daily needs by realizing an orderly and balanced lifestyle. 


\section{Pendahuluan}

Kehidupan pada dasarnya merupakan serangkaian perkembangan yang kontinu dari lahir sampai mati. Setiap perkembangan mengandung pengertian adanya suatu proses menuju kematangan yang meliputi aspek jasmaniah, rohaniah dan sosial. Bila seorang individu telah mencapai periode kematangan, baik aspek fisik, psikis maupun sosialyang umumnya dapat dicapai pada usia remaja hingga dewasa, maka periode berikutnya adalah tahap kemantapan dan untuk selanjutnya adalah periode penurunan. ${ }^{1}$ Kesehatan reproduksi wanita merupakan keadaan sejahtera fisik, mental dan sosial yang secara utuh bebas dari penyakit atau kecacatan dalam semua hal yang berkaitan dengan sistem reproduksi serta fungsi dan prosesnya, ruang lingkup kesehatan reproduksi sebenarnya sangat luas karena mencakup kehidupan manusia sejak lahir hingga mati, termasuk didalamnya masa menopause.

Sindrom menopause dialami oleh banyak wanita diseluruh dunia $\pm 70-80$ wanita di Eropa, 60\% di Amerika, 57\% Malaysia, $18 \%$ di Cina dan di Jepang serta di Indonesia sebesar 10\%, dari beberapa data tersebut tampak bahwa terjadi perbedaan data yang mencolok salah satu yang menjadi faktor penyebabnya adalah adanya perbedaan pola makan dari tiap-tiap negara tersebut. Perempuan perimenopause dipengaruhi oleh berbagai macam faktor. Diantaranya yaitu pendidikan, sosiol ekonomi, dan pekerjaan. Perempuan yang banyak mengalami kekhawatiran berasal dari orang-orang yang berpendidikan tinggi dan perekonomian menengah keatas, sindrome menopause dialami oleh banyak perempuan hampir diseluruh dunia, sekitar 70-80\% perempuan Eropa, 60\% di Amerika, $57 \%$ di Malaysia, $18 \%$ di Cina dan $10 \%$ di Jepang dan Indonesia.

Berdasarkan data BPS pada tahun 2014 ada 16,5 juta manusia usia lanjut yang tersebar dalam dengan komposisi 7,8 juta jiwa $(47,3 \%)$ laki - laki dan pada wanita 8,7 juta jiwa $(52,7 \%)$. Sedangkan hasil sensus penduduk tahun 2015 Indonesia saat ini termasuk lima besar negara dengan jumlah penduduk lanjut usia terbanyak di dunia yaitu mencapai 18,1 juta jiwa $(7,6 \%)$ dari jumlah penduduk, jumlah menopause 60 tahun atau lebih diperkirakan akan terus meningkat sehingga pada tahun 2025 diperkirakan mencapai jumlah 36 juta.

Akibatnya perempuan itu akan menjadi kurang percaya diri, merasa tidak diperhatikan, tidak dihargai, merasa stress, dan khawatir berkepanjangan tentang perubahan fisiknya, para perempuan usia lanjut tersebut juga rentang terhadap penyakit degeneratif misalnya osteoporosis, penyakit jantung koroner, kanker, dan darah tinggi, jika kondisi ini tidak bisa dibatasi akan berkembang menjadi stress yang berdampak buruk pada kehidupan sosial perempuan yang akan merangsang otak sehingga dapat menggangu keseimbangan hormon dan akhirnya berakibat buruk pada kesehatan tubuh. ${ }^{4}$ Menopause merupakan masa berhentinya menstruasi yang terjadi pada perempuan dengan rentang usia 48 sampai 55 tahun, masa ini sangat kompleks bagi perempuan karena berkaitan dengan keadaan fisik dan kejiwaannya, selain perempuan mengalami stress fisik juga mengalami stress psikologi yang mempengaruhi keadaan emosi dalam menghadapi hal normal sebagaimana yang dijalani oleh semua perempuan.

Salah satu permasalahan meningkatnya jumlah wanita menopause adalah kemandirian perimenopause, kemandirian perimenopause merupakan kemampuan wanita menghadapi masa menopause untuk tidak tergantung pada orang lain serta bertanggung jawab atas apa yang dilakukan. Kemandirian sebagai perilaku yang aktivitasnya diarahkan pada diri sendiri, tidak mengharapkan pengarahan dari orang lain dan mencoba menyelesaikan masalahnya sendiri tanpa meminta bantuan dari orang lain. Perimenopause yang mandiri menunjukan suatu keadaan dimana seseorang yang memiliki keputusan dan 
inisiatif untuk mengatasi masalah yang dihadapi, memiliki kepercayaan diri dalam mengerjakan tugas-tugasnya, bertanggung jawab terhadap apa yang dilakukan. Kemandirian juga merupakan suatu sikap dimana individu akan terus belajar untuk bersikap mandiri dalam menghadapi berbagai situasi dilingkungan sehingga individu pada akhirnya akan mampu berpikir dan bertindak sendiri.

Perimenopause yang tidak dapat melakukan aktivitas secara mandiri umumnya memiliki kondisi kesehatan yang tidak baik. Mereka mengalami keluhan $\geq$ $60 \%$ dari keluhan yang umum diderita perimenopause, perimenopause tidak bisa melihat karena menderita kebutaan, mengalami kelumpuhan karena sudah lama menderita strok. Perimenopause yang tidak mandiri juga disebabkan karena kondisi tubuh perimenopause yang sudah melemah karena proses menua. Sehingga perimenopause sangat bergantung pada bantuan orang lain terutama anak-anak dan keluarganya.

Hasil penelitian dengan judul Pengaruh fungsi keluarga Terhadap Kemandirian perimenopause di Puskesmas Tegal Gundil Bogor Utara 2014, bahwa Ada pengaruh langsung dukungan keluarga terhadap kemandirian perimenopause di Puskesmas Tegal Gundil Bogor Utara sebesar 26.7\%. Fungsi keluarga merupakan hal yang penting dalam mewujudkan perimenopause yang sejahtera lahir dan batin. Dukungan lahir dapat diperankan oleh siapa saja, tetapi kebutuhan emosional dan batin memerlukan keterlibatkan keluarga mereka secara intensif dan bahkan dapat memperkuat hubungan antar generasi. Keberadaan suatu hubungan diantara dukungan keluarga dengan sikap kemandirian dari perimenopause dengan bantuan dan suatu pendampingan dari keluarga, perimenopause akan mudah melakukan kemandiriannya pada kehidupan keseharian, sebab perimenopause akan merasa diberi perhatian dengan demikian bisa tergapai suatu kemandirian yang baik. Dalam memberikan bantuan pada para perimenopause supaya tetap mampu melakukan aktivitas, diperlukan sebuah dukungan dari keluarga. Fungsi keluarga menjadi sebuah bantuan yang dapat diterima oleh individu dari orang-orang tertentu pada kehidupannya dan ada pada lingkungan sosial tertentu, yang mampu membuat si penerima mempunyai rasa diberikan perhatian, dihargai dan dicintai.

Oleh karena itu, maka peneliti melakukan penelitian di Wilayah kerja Batununggal Bandung Jawa. Didapatkan hasil prasurvei yang dilakukan pada tanggal 18 Juli 2017 terhadap 20 perimenopause di wilayah kerja di Wilayah Kecamatan Batununggal Bandung Propinsi Jawa Barat yang tinggal dengan keluarga, Survei dan observasi pendahuluan dilakukan terhadap 20 perimenopause di Wilayah Kecamatan Batununggal Bandung Propinsi Jawa Barat Tahun 2017 yang tinggal dengan keluarga, sebanyak 18 orang dengan status kesehatan yang baik, lingkungan yang mendukung karena tidak ada benda-benda atau tempat yang membahayakan perimenopause. Kemandirian perimenopause dalam memenuhi kebutuhan activities daily living (adl) dipengaruhi oleh beberapa faktor yaitu lingkungan sosial, peran tokoh masyarakat, fungsi keluarga, dan motivasi lansia. Berdasarkan uraian di atas maka perlu adanya penelitian lebih lanjut kemandirian perimenopause dalam memenuhi kebutuhan activities daily living (adl), karena lansia juga harus lebih diperhatikan agar lansia berpengaruh terhadap kehidupan selamjutnya.

Kemandirian perimenopause dalam memenuhi kebutuhan activities daily living (adl) agar dapat mengurangi dampak negatif yang terjadi yang dimulai dari faktor internal dan eksternal pada lansia. Oleh karena itu, maka peneliti melakukan penelitian tentang "pengaruh lingkungan sosial, peran tokoh masyarakat, fungsi keluarga dan motivasi lansia terhadap kemandirian perimenopause dalam memenuhi kebutuhan activities daily 
living (adl) di Wilayah Kecamatan Batununggal Bandung tahun 2017”.

\section{Metodologi}

Jenis penelitian ini menggunakan metode deskriptif analitik, dengan desain penelitian cross sectional (potong lintang). Penelitian ini dilaksanakan di Selatan. Waktu penelitian inWilayah Kecamatan Batununggal Bandung pada November Februari 2018. Populasi penelitian adalah seluruh lansia yang berada di Wilayah Kecamatan Batununggal Bandung yang berjumlah 285 orang. Sampel dalam penelitian ini adalah lansia yang berada di Wilayah Kecamatan Batununggal Bandung

Jumlah sampel minimal adalah $5 \mathrm{x}$ variabel bebas/indikator, dan jumlah sampel maksimal adalah $10 \mathrm{x}$ variabel bebas/indikator. Sehingga, karena jumlah indikator dalam penelitian ini adalah 15 indikator, maka jumlah sampel minimal adalah 100 lansia yang berada di Wilayah Kecamatan Batununggal. Jadi jumlah rentang (range) jumlah sampel minimal adalah $50-100$ lansia yang berada di Wilayah Kecamatan Batununggal. Dalam Penelitian ini peneliti mengambil sebanyak 75 lansia yang berada di Wilayah Kecamatan Batununggal sebagai sampel.

\section{Hasil dan Pembahasan}

Responden berdasarkan umurnya paling banyak menunjukkan bahwa sebagian besar wanita perimenopause adalah berumur 42 tahun tahun sebanyak $18 \quad(24,0 \%)$ responden. Sedangkan berdasarkan pendidikan wanita perimenopause memperlihatkan bahwa sebagian besar responden adalah berpendidikan SMA, yaitu sebanyak $32(42,7 \%)$ responden.

. Berdasarkan gambar 1, menunjukkan bahwa konstruk fungsi keluarga diukur dengan tiga indikator reflektif yaitu pendampingan, perawatan, pengawasan. Peran tokoh masyarakat diukur dengan tiga indikator yaitu pembinaan, penyuluhan, motivator. Motivasi diukur dengan tiga indikator yaitu harapan, tujuan, kebutuhan lingkungan sosial dan kemandirian perimenopouse tidak memiliki indikator.

Berdasarkan gambar 1, terlihat bahwa nilai loading factor tertinggi yaitu pengaruh peran lingkungan sesial ke kemandirian yaitu sebesar 0,789 serta nilai terendah yaitu pengaruh lingkungan sosial ke peran tokoh masyarakat yaitu sebesar 0,335 dan pengaruh lingkungan sosial ke fungsi keluarga sebesar 0,665 . Nilai paling kecil adalah sebesar 0,334 untuk indikator FS1. Berarti indikator yang dipergunakan dalam penelitian ini adalah valid atau telah memenuhi convergent validity.

Pengukuran dengan membandingkan nilai AVE (Average Variance Extracted) setiap konstruk dengan korelasi antara konstruk dengan konstruk lainnya. Pada evaluasi AVE di atas pada kontruk fungsi keluarga sebesar 0.815 kemandirian perimenopus sebesar 1, 000 lingkungan sosial sebesar 1,000, motivasi sebesar 0,813 dan peran tokoh masyarakat sebesar 0,877 dinyatakan valid karena nilai AVE di atas 0,5 dengan demikian dapat disimpulkan bahwa evaluasi pengukuran model memilki discriminat validity yang baik. Didapat nilai cronbach alpha pada semua variabel berkisar 0.716 hingga 1,000 yang berarti semua indikator handal dalam mereflesikan variabelnya (nilai cronbach alpha $>0,70$ ).

Tabel 1.Evaluasi Nilai R Square Model Pengaruh Lingkungan Sosial, Peran Tokoh Masyarakat, Fungsi Keluarga, Motivasi, dan Kemandirian

Nilai $R$-Square berfungsi untuk menilai besaran keragaman atau variasi data penelitian terhadap fenomena yang sedang dikaji. Selanjutnya dilakukan uji Inner Model, pengujian terhadap model struktural dilakukan dengan melihat nilai $R$-Square yang merupakan uji goodness-fit model. Berikut ini adalah hasil pengukuran nilai $R$ Square, yang juga merupakan nilai goodness of fit model 


\begin{tabular}{cc}
\hline Variabel & R Square \\
\hline Fungsi Keluarga & 0,664570 \\
Kemandirian & 0,789044 \\
Perimenopause & \\
Lingkungan Sosial & 0,771487 \\
Motivasi & 0,334541 \\
Peran Tokoh & \\
Masyarakat & \\
\hline
\end{tabular}

Berdasarkan, nilai $R$-Square tertinggi terdapat pada variabel, lingkungan sosial berkontribusi terhadap peran tokoh masyarakat sebesar 0,334541 , lingkungan sosial dan peran tokoh masyarakat berkontribusi terhadap fungsi keluarga sebesar 0,664570, lingkungan sosial, peran tokoh masyarakat dan fungsi keluarga berkontribusi terhadap motivasi sebesar 0,771487, dan lingkungan sosial, peran tokoh masyarakat, fungsi keluarga dan motivasi wanita perimenopause berkontribusi terhadap kemandirian sebesar 0,789044. Berdasarkan hasil pengukuran tersebut dapat disimpulkan bahwa variabilitas lingkungan sosial berkontribusi terhadap variabilitas peran tokoh masyarakat sebesar $33,45 \%$ dan $66,55 \%$ dijelaskan oleh variabel lain yang tidak diteliti.

Variabilitas lingkungan sosial dan peran tokoh masyarakat berkontribusi terhadap variabilitas fungsi keluarga sebesar $66,46 \%$ dan 33,54\% dijelaskan oleh variabel lain yang tidak diteliti. Variabilitas lingkungan sosial, peran tokoh masyarakat dan fungsi keluarga berkontribusi terhadap variabilitas motivasi sebesar $77,15 \%$ dan $22,85 \%$ dijelaskan oleh variabel lain yang tidak diteliti.

Variabilitas lingkungan sosial, peran tokoh masyarakat, fungsi keluarga dan motivasi wanita perimenopause berkontribusi terhadap variabilitas kemandirian sebesar $78,90 \%$ dan $21,10 \%$ dijelaskan oleh variabel lain yang tidak diteliti.

Hasil evaluasi signifikan outer model diatur dalam output PLS di bawah ini dengan mengevaluasi refleksi nilai $T$ statistic indikator terhadap variabelnya. Evaluasi signifikansi outer model dilakukan untuk menilai signifikansi konstruk laten dengan konstruknya, yaitu dengan membandingkan nilai $\mathrm{t}$ statistik masingmasing konstruk laten dengan nilai $\alpha=$ 0,05 (1,96). Untuk mengukur nilai t statistik dilakukan bootstrapping pada model dengan hasil sebagai berikut:

Lingkungan sosial berkontribusi terhadap peran tokoh masyarakat sebesar 0,334541 , lingkungan sosial dan peran tokoh masyarakat berkontribusi terhadap fungsi keluarga sebesar 0,664570, lingkungan sosial, peran tokoh masyarakat dan fungsi keluarga berkontribusi terhadap motivasi sebesar 0,771487, dan lingkungan sosial, peran tokoh masyarakat, fungsi keluarga dan motivasi wanita perimenopause berkontribusi terhadap kemandirian sebesar 0,789044 .

Berdasarkan hasil pengukuran tersebut dapat disimpulkan bahwa variabilitas lingkungan sosial berkontribusi terhadap variabilitas peran tokoh masyarakat sebesar $33,45 \%$ dan $66,55 \%$ dijelaskan oleh variabel lain yang tidak diteliti. Lingkungan sosial dan peran tokoh masyarakat berkontribusi terhadap variabilitas fungsi keluarga sebesar $66,46 \%$ dan $33,54 \%$ dijelaskan oleh variabel lain yang tidak diteliti. Variabilitas lingkungan sosial, peran tokoh masyarakat dan fungsi keluarga berkontribusi terhadap variabilitas motivasi sebesar $77,15 \%$ dan $22,85 \%$ dijelaskan oleh variabel lain yang tidak diteliti.

Variabilitas lingkungan sosial, peran tokoh masyarakat, fungsi keluarga dan motivasi wanita perimenopause berkontribusi terhadap variabilitas kemandirian sebesar $78,90 \%$ dan $21,10 \%$ dijelaskan oleh variabel lain yang tidak diteliti.

Terlihat bahwa lingkungan sosial berpengaruh positif terhadap peran tokoh masyarakat, hasil uji menunjukkan ada pengaruh positif 0,578395 , sedangkan nilai T-Statistic sebesar 5,988875 dan signifikan pada $\alpha=5 \%$. Nilai $T$-Statistic tersebut berada di atas nilai kritis $(1,96)$. 
Lingkungan sosial berpengaruh positif terhadap fungsi keluarga, hasil uji menunjukkan ada pengaruh positif 0,434999, sedangkan nilai T-Statistic sebesar 4,576782 dan signifikan pada $\alpha=5 \%$. Nilai $T$-Statistic tersebut berada di atas nilai kritis $(1,96)$. Lingkungan sosial berpengaruh positif terhadap motivasi, hasil uji menunjukkan ada pengaruh positif 0,246512, sedangkan nilai T-Statistic sebesar 4,065269 dan signifikan pada $\alpha=5 \%$. Nilai T-Statistic tersebut berada di atas nilai kritis $(1,96)$.

Lingkungan sosial berpengaruh positif terhadap kemandirian, hasil uji menunjukkan ada pengaruh positif 0,191167, sedangkan nilai T-Statistic sebesar 3,974598 dan signifikan pada $\alpha=5 \%$. Nilai $T$-Statistic tersebut berada di atas nilai kritis $(1,96)$.

Peran tokoh masyarakat berpengaruh positif terhadap fungsi keluarga, hasil uji menunjukkan ada pengaruh positif 0,482326, sedangkan nilai T-Statistic sebesar 4,767703 dan signifikan pada $\alpha=5 \%$. Nilai $T$-Statistic tersebut berada di atas nilai kritis $(1,96)$.

Peran tokoh masyarakat berpengaruh positif terhadap motivasi, hasil uji menunjukkan ada pengaruh positif 0,165729, sedangkan nilai T-Statistic sebesar 2,271652 dan signifikan pada $\alpha=5 \%$. Nilai $T$-Statistic tersebut berada di atas nilai kritis $(1,96)$.

Peran tokoh masyarakat berpengaruh positif terhadap kemandirian, hasil uji menunjukkan ada pengaruh positif 0,271296, sedangkan nilai T-Statistic sebesar 2,946731 dan signifikan pada $\alpha=5 \%$. Nilai T-Statistic tersebut berada di atas nilai kritis $(1,96)$.

Fungsi keluarga berpengaruh positif terhadap motivasi, hasil uji menunjukkan ada pengaruh positif 0,553586 , sedangkan nilai T-Statistic sebesar 7,496141 dan signifikan pada $\alpha=5 \%$. Nilai T-Statistic tersebut berada di atas nilai kritis $(1,96)$.
Fungsi keluarga berpengaruh positif terhadap kemandirian, hasil uji menunjukkan ada pengaruh positif 0,322206, sedangkan nilai T-Statistic sebesar 3,379271 dan signifikan pada $\alpha=5 \%$. Nilai $T$-Statistic tersebut berada di atas nilai kritis $(1,96)$.

Motivasi wanita perimenopause berpengaruh positif terhadap kemandirian, hasil uji menunjukkan ada pengaruh positif 0,209317, sedangkan nilai T-Statistic sebesar 2,048239 dan signifikan pada $\alpha=5 \%$. Nilai T-Statistic tersebut berada di atas nilai kritis $(1,96)$

Tabel 2. Presentase Pengaruh Antar Variabel Terhadap Variabel Kemandirian pada Model

\begin{tabular}{|c|c|c|c|c|c|c|c|}
\hline Variabel & $\begin{array}{l}\text { LV } \\
\text { Corr } \\
\text { elati } \\
\text { on }\end{array}$ & $\begin{array}{c}\text { Dire } \\
\text { ct } \\
\text { Rho }\end{array}$ & $\begin{array}{l}\text { Inde } \\
\text { rect } \\
\text { Rho }\end{array}$ & $\begin{array}{l}\text { To } \\
\text { tal }\end{array}$ & $\begin{array}{c}D i \\
r e \\
c t \\
( \\
\% \\
)\end{array}$ & $\begin{array}{c}\text { Indere } \\
\text { ct } \\
(\%)\end{array}$ & $\begin{array}{c}\text { Tota } \\
l \\
(\%)\end{array}$ \\
\hline $\begin{array}{l}\text { Lingkung } \\
\text { an Sosial }\end{array}$ & $\begin{array}{c}0,73 \\
3\end{array}$ & $\begin{array}{c}0,19 \\
1\end{array}$ & $\begin{array}{c}0,54 \\
1\end{array}$ & $\begin{array}{c}0 \\
73 \\
3\end{array}$ & $\begin{array}{l}14 \\
0 \\
0\end{array}$ & 0,72 & $\begin{array}{c}14,7 \\
2\end{array}$ \\
\hline $\begin{array}{c}\text { Peran } \\
\text { Tokoh } \\
\text { Masyarak } \\
\text { at }\end{array}$ & $\begin{array}{c}0,76 \\
8\end{array}$ & $\begin{array}{c}0,27 \\
1\end{array}$ & $\begin{array}{c}0,24 \\
6\end{array}$ & $\begin{array}{c}0, \\
51 \\
7\end{array}$ & $\begin{array}{l}20 \\
, 8 \\
3\end{array}$ & 0,44 & $\begin{array}{c}21,2 \\
7\end{array}$ \\
\hline $\begin{array}{l}\text { Fungsi } \\
\text { Keluarga }\end{array}$ & $\begin{array}{c}0,83 \\
6\end{array}$ & $\begin{array}{c}0,32 \\
2\end{array}$ & $\begin{array}{c}0,11 \\
6\end{array}$ & $\begin{array}{c}0, \\
43 \\
8\end{array}$ & $\begin{array}{c}26 \\
, 9 \\
4\end{array}$ & 0,29 & $\begin{array}{c}27,2 \\
2\end{array}$ \\
\hline \multirow[t]{2}{*}{ Motivasi } & $\begin{array}{c}0,81 \\
8\end{array}$ & $\begin{array}{c}0,20 \\
9\end{array}$ & & $\begin{array}{c}0, \\
20 \\
9\end{array}$ & $\begin{array}{l}17 \\
1 \\
3\end{array}$ & & $\begin{array}{c}17,1 \\
3\end{array}$ \\
\hline & & $\begin{array}{c}\text { Tota } \\
1\end{array}$ & & & $\begin{array}{l}78 \\
, 9 \\
0\end{array}$ & 1,45 & $\begin{array}{c}80,3 \\
5\end{array}$ \\
\hline
\end{tabular}

Lingkungan sosial berpengaruh secara langsung dan tidak langsung terhadap kemandirian. Hasil uji koefisien parameter antara lingkungan sosial terhadap kemandirian didapatkan pengaruh langsung sebesar $14,00 \%$, sedangkan untuk pengaruh tidak langsung antara lingkungan sosial terhadap kemandirian melalui peran tokoh masyarakat, fungsi keluarga dan motivasi didapatkan nilai sebesar $0,72 \%$.

Peran tokoh masyarakat berpengaruh secara langsung dan tidak langsung terhadap kemandirian. Hasil uji koefisien parameter antara peran tokoh masyarakat terhadap kemandirian didapatkan pengaruh langsung sebesar $20,83 \%$, sedangkan untuk pengaruh 
tidak langsung antara peran tokoh masyarakat terhadap kemandirian melalui fungsi keluarga, maupun motivasi didapatkan nilai sebesar $0,44 \%$.

Fungsi keluarga berpengaruh secara langsung dan tidak langsung terhadap kemandirian. Hasil uji koefisien parameter antara fungsi keluarga terhadap kemandirian didapatkan pengaruh langsung sebesar $26,94 \%$, sedangkan untuk pengaruh tidak langsung antara fungsi keluarga terhadap kemandirian melalui motivasi didapatkan nilai sebesar $0,29 \%$.

Motivasi wanita perimenopause berpengaruh secara langsung terhadap kemandirian. Hasil uji koefisien parameter antara motivasi terhadap kemandirian didapatkan pengaruh langsung sebesar $17,13 \%$.

Sehingga nilai dari masing-masing pengaruh langsung variabel laten eksogen tersebut apabila secara bersama-sama menunjukkan kesesuaian dengan kata lain hal ini menyatakan bahwa variabel lingkungan sosial, peran tokoh masyarakat, fungsi keluarga, dan motivasi wanita perimenopause mampu menjelaskan variabel kemandirian sebesar $(14,00 \%+$ $20,83 \%+26,94 \%+17,13 \%)=78,90 \%$. Sedangkan pengaruh tidak langsung dari variabel lingkungan sosial, peran tokoh masyarakat, fungsi keluarga, dan motivasi wanita perimenopause terhadap variabel kemandirian sebesar $(0,72 \%+0,44 \%+$ $0,29 \%)=1,45 \%$. Jadi total pengaruh langsung dan tidak langsung sebesar $80,35 \%$.

Nilai Q - Square menjelaskan bahwa nilai outer model mempunyai 0,996 atau 99,6\% keragaman data pada variabel kemandirian pada lansia yang dipengaruhi oleh lingkungan sosial, peran tokoh masyarakat, fungsi keluarga, dan motivasi. mampu mengkaji fenomena yang dipakai dalam penelitian, sedangkan $0,4 \%$ adalah komponen lain yang tidak ada dalam penelitian ini.

\section{Pembahasan}

\section{Pengaruh Variabel Lingkungan Sosial Terhadap Peran Tokoh Masyarakat}

Lingkungan sosial berpengaruh positif terhadap peran tokoh masyarakat, hasil uji menunjukkan ada pengaruh positif 0,578395, sedangkan nilai T-Statistic sebesar 5,988875 dan signifikan pada $\alpha=5 \%$. Nilai $T$-Statistic tersebut berada di atas nilai kritis $(1,96)$. Lingkungan sosial berpengaruh positif terhadap peran tokoh masyarakat sebesar $33,45 \%$.

Lingkungan sosial adalah interaksi antara masyarakat dengan lingkungannya, atau lingkungan yang terdiri dari mahluk sosial yaitu manusia. Lingkungan sosial seseorang pertama di bentuk dalam lingkungan keluarga, lalu lingkungan keluarganya merupakan media pertama yang berpengaruh terhadap perilaku seseorang khusunya anak-anak didapat dengan nilai $\mathrm{T}$ statistik sebesar 3,939>1,96. Dengan demikian hasil penelitian ini ada pengaruh lingkungan sosial terhadap peran tokoh masyarakat. Sehingga parameter lingkungan sosial terhadap peran tokoh masyarakat dikatakan signifikan.

Hasil penelitian ini sejalan dengan penelitian yang berjudul pengaruh lingkungan sosial, peran tokoh masyarakat terhadap kemandirian pada lansia. Hasil uji statistik pada menunjukkan bahwa ada hubungan yang bermakna antara lingkungan sosial terhadap peran tokoh masyarakat dengan kemandirian lansia dengan nilai $p$ $=0,0003$. Nilai RP sebesar 1,5 (CI95\%= 1,21-1,91) menjelaskan lansia yang menerima anggota keluarag terhadap kemandirian.. Persentase lansia yang menerima di bantu oleh anggota keluargaa dan kemandirian lasia sebesar $60,52 \%$. secara statistik, variabel kemandirian lansia mempunyai hubungan yang bermakna dengan tokoh masyarakat, $\mathrm{p}=0.017$ $(\mathrm{CI} 95 \%=1,04-1,63)$. Nilai RP sebesar 1,3 menjelaskan bahwa lansia mebutuhkan keluarga dan tokoh masyarakat. ${ }^{11}$ 
Lingkungan sosial merupakan salah satu faktor yang dapat mempengaruhi seseorang atau kelompok untuk dapat melakukan sesuatu tindakan serta perubahan-perubahan perilaku setiap individu. Lingkungan sosial yang kita kenal antara lain lingkungan keluarga, lingkungan teman sebaya, dan lingkungan tetangga. Keluarga merupakan lingkungan sosial yang pertama kali dikenal oleh individu sejak lahir.

Menurut asumsi peneliti, lingkungan sosial membentuk sistem pergaulan yang besar peranannya dalam membentuk kepribadian seseorang, dan terjadilah interaksi antara orang atau masyarakat dengan lingkungannya sehingga muncul keikutsertaan tokoh masyarakat dalam interaksi tersebut. Contohnya: gotong royong, melakukan program kali bersih atau membersihkan kali (sungai), membersihkan solokan yang tersumbat oleh sampah, dan sebagainya.

\section{Pengaruh Variabel Langsung Lingkungan Sosial Terhadap Fungsi Keluarga}

Lingkungan sosial berpengaruh positif terhadap fungsi keluarga, hasil uji menunjukkan ada pengaruh positif 0,434999, sedangkan nilai T-Statistic sebesar 4,576782 dan signifikan pada $\alpha=5 \%$. Nilai $T$-Statistic tersebut berada di atas nilai kritis $(1,96)$. Lingkungan sosial berpengaruh positif terhadap fungsi keluarga sebesar $31,06 \%$. Sehingga parameter teman sebaya terhadap kemandirian lansia dikatakan signifikan.

Hasil penelitian pada beberapa studi epidemiologi sosial yang menyebutkan jika dukungan masyarakat dapat mengurangi efek stres, sehingga mengurangi insidensi penyakit Ketersediaan dukungan berpengaruh positif pada sikap seseorang terhadap perawatan kesehatan, membantu penyesuaian psikologis terhadap penyakit, mencegah stres, dan bahkan meningkatkan angka kelangsungan hidup. dukungan merupakan sebagai faktor yang bermakna dalam menahan stress bagi pasien yang menderita gangguan jiwa berat maupun bagi keluarga penderita gangguan jiwa. Fungsi keluarga terhadap anggotanya antara lain adalah fungsi perawatan kesehatan, yaitu keluarga memberikan asuhan keperawatan kepada anggota keluarga dan salah satunya adalah melakukan dukungan.

Di Indonesia, proses pengkajian asuhan keperawatan keluarga pada format pengkajian menurut Friedman. Dalam format pengkajian tersebut, Friedman menguraikan delapan komponen yang harus dikaji pada keluarga, yaitu data umum (demografi), riwayat dan tahap perkembangan keluarga, keadaan lingkungan, struktur keluarga, fungsi keluarga, stress dan koping keluarga, pemeriksaan esehatan tiap anggota keluarga, dan harapan keluarga

Menurut asumsi peneliti lingkungan sosial dapat merubah suasana keluarga jika adanya intervensi dari lingkungan sosial seperti norma atau nilai-nilai sosial yang masuk ke dalam keluarga sehingga membentuk suatu fungsi baru dalam keluarga.

\section{Pengaruh Variabel Lingkungan Sosial Terhadap Motivasi}

Lingkungan sosial berpengaruh positif terhadap motivasi, hasil uji menunjukkan ada pengaruh positif 0,246512, sedangkan nilai T-Statistic sebesar 4,065269 dan signifikan pada $\alpha=5 \%$. Nilai T-Statistic tersebut berada di atas nilai kritis $(1,96)$. Lingkungan sosial berpengaruh positif terhadap motivasi sebesar $18,18 \%$. Dengan demikian hasil penelitian ini ada pengaruh faktor lingkungan sosial terhadap motivasi Sehingga parameter lingkungan sosial terhadap motivasi dikatakan signifikan.

Hal ini sejalan dengan penelitian yang berjudul faktor-faktor yang dilihat pada setiap variabel yaitu variabel aktivitas sehari-hari dan successful aging menunjukkan bahwa keduanya memiliki keterkaitan hubungan. Keterkaitan hubungan 
antara aktivitas sehari-hari dengan successful aging ditunjukkan oleh hasil penghitungan yang menunjukkan bahwa prosentase hubungan variabel aktivitas sehari-hari dan 14 variabel adalah sebesar $14,2 \%$ sedangkan sisanya yaitu sebesar $85,8 \%$ berhubungan dengan faktor-faktor lainnya yang tidak diteliti dalam penelitian ini seperti usia, latar belakang pendidikan, jenis kelamin, status sosial ekonomi, latar belakang keluarga atau lingkungan, budaya, kondisi psikologis dan lain-lain.

Menurut asumsi peneliti, perubahan peran sosial dan status fungsional individu memperlihatkan bahwa lansia akan merasakan kepuasannya dalam melakukan aktivitas sehari-hari menjadi jauh lebih penting daripada kuantitas dari aktivitas yang dilakukan. Misalnya, mengunjungi saudara atau teman, melakukan aktivitas keagamaan, mengikuti aktivitas kelompok lansia, melakukan kegiatan membaca atau menulis, musik, seni, menjalankan hobi, berkebun, menanam tanaman, mengikuti kegiatan warga atau sosial, membersihkan halaman rumah, kerja bakti warga, dan lainlain. Contoh-contoh aktivitas sehari-hari diatas mampu memberikan kesempatan pada lansia untuk terus terlibat aktif dalam berbagai kegiatan, terus bekerja memberikan kontribusi bagi kepuasan dan kebahagiaan hidup secara berarti bagi usia lanjut.

\section{Pengaruh Variabel Lingkungan Sosial Terhadap Kemandirian Perimenopause}

Lingkungan sosial berpengaruh positif terhadap kemandirian, hasil uji menunjukkan ada pengaruh positif 0,191167, sedangkan nilai T-Statistic sebesar 3,974598 dan signifikan pada $\alpha=5 \%$. Nilai $T$-Statistic tersebut berada di atas nilai kritis $(1,96)$. Lingkungan sosial berpengaruh secara tidak langsung terhadap kemandirian. Hasil uji koefisien parameter antara lingkungan sosial terhadap kemandirian didapatkan pengaruh tidak langsung antara lingkungan sosial terhadap kemandirian melalui peran tokoh masyarakat, fungsi keluarga dan motivasi didapatkan nilai sebesar $0,72 \%$. Sehingga parameter lingkungan sosial terhadap kemandirian di katakan signifikan.

Salah satu faktor yang mempengaruhi kemandirian perimenopause adalah lingkungan sosial. Jika dilihat pada faktor lingkungan sehat, diketahui bahwa penduduk yang tinggal di lingkungan sehat lebih banyak yang memiliki status kesehatan dan kemandirian yang baik dibandingkan dengan penduduk yang tinggal di lingkungan tidak sehat. Perilaku perimenopause dalam hal pemeliharaan kebersihan lingkungan, misalnya $\mathrm{BAB}$ dan BAK pada umumnya sudah dilakukan di jamban, akan tetapi ada sebagian yang membuang ludah sembarangan, tidak menyapu lantai atau halaman, dan tidak pernah membersihkan kamarnya. Kebersihan lingkungan dapat mencegah terjadinya penularan infeksi dan juga memberikan suasana nyaman. Untuk itu perimenopause yang masih aktif perlu diberdayakan untuk ikut serta dalam menjaga kebersihan lingkungan sesuai dengan kemampuannya. Pada umumnya perimenopause tidak mengikuti asuransi kesehatan dan pemeriksaan kesehatan hanya bila sakit saja karena pengertian sehat menurut masyarakat adalah tidak adanya keluhan sakit. Sebanyak 66,6\% keluarga telah mampu mempertahankan suasana rumah yang menguntungkan kesehatan perimenopause, misalnya: berbicara pelan tapi dapat dimengerti $(78,3 \%)$, mengajak perimenopause untuk bercakap-cakap $(58,3 \%)$, tetapi $51,7 \%$ keluarga belum menyediakan makanan yang bervariasi, dan $33,3 \%$ keluarga menganggap pembicaraan perimenopause itu membosankan. ${ }^{7}$

Lingkungan sosial merupakan salah satu dari aktivitas sehari-hari yang dilakukan oleh perimenopause. Perimenopause yang sukses adalah perimenopause yang mempunyai aktivitas sosial di lingkungannya. Aktivitas sosial merupakan kegiatan yang dilakukan bersama dengan masyarakat di lingkungan sekitar. Kemandirian perimenopause dalam aktivitas sehari-hari diantaranya tentang 
faktor-faktor yang berhubungan dengan kemandirian perimenopause, salah satunya adalah fungsi keluarga, namun hubungan fungsi keluarga dengan kemandirian perimenopause dalam pemenuhan kebutuhan sehari-hari masih perlu dibuktikan. $^{7}$

Penelitian Erlinafsiah lingkungan sosial menunjukan suatu keadaan seseorang yang mengalami ketidakmampuan untuk mengadakan hubungan dengan orang lain atau dengan lingkungan disekitarnya secara wajar dan hidup dalam khayalan sendiri yang tidak realistis. Berdasarkan penelitian yang dilakukan oleh Sabri (2013) di Kecamatan Cakung Jakarta Timur dengan jumlah sampel total populasi 152 responden, seluruh responden berusia diatas 60 tahun. Didapatkan hasil penelitian $62,5 \%$ usia lanjut di Kecamatan Cakung mempunyai psikososial sehat dan $37,5 \%$ mengalami gangguan pada masalah kesehatan psikososial karena tidak ada dukungan dari lingkungan sosial di Panti Werdha Wisma Mulia Kecamatan Cakung Jakarta Timur yang berjumlah 65 orang pada bulan Oktober 2013 diperoleh data bahwa dari 10 orang perimenopause, 6 diantaranya memiliki tanda dan gejala mengalami isolasi sosial (menarik diri) dengan keluhan diantaranya perasaan kesepian, lebih suka 3 menyendiri, merasa tidak nyaman berada didekat orang lain dan gejala objektif seperti menolak saat diajak berinteraksi, dan tampak menyendiri di dalam ruangan, sedangkan alasan perimenopause menarik diri diantaranya mengatakan karena ditinggal pasangan, kehilangan pekerjaan dan sahabat karib serta keinginan untuk tidak berinteraksi dengan orang lain.

Menurut asumsi peneliti, pemberian kesempatan dan menjadikan wanita perimenopause sebagai tempat bertanya (sesepuh) dapat menimbulkan perasaan berharga pada dirnya. Mengingat wanita perimenopause perlu mempersiapkan diri dalam memasuki fase yang baru sehingga dukungan sosial diperlukan agar tidak mengalami depresi dalam beradaptasi dengan kondisi baru atau lingkungan baru tersebut. Lingkungan disinyalir mempunyai hubungan yang cukup berperan terhadap Kemandirian Perimenopause.

\section{Pengaruh Variabel Peran Tokoh Masyarakat Terhadap Fungsi Keluarga}

Peran tokoh masyarakat berpengaruh positif terhadap fungsi keluarga, hasil uji menunjukkan ada pengaruh positif 0,482326, sedangkan nilai T-Statistic sebesar 4,767703 dan signifikan pada $\alpha=5 \%$. Nilai T-Statistic tersebut berada di atas nilai kritis (1,96). Peran tokoh masyarakat berpengaruh positif terhadap fungsi keluarga sebesar 35,40\%. Dengan demikian hasil penelitiaan ini ada pengaruh peran tokoh masyarajat terhadap fungsi keluarga sehingga parameter persepsi terhadap kemandirian dikatakan signifikan.

Hal ini sejalan dengan penelitian yang berjudul peran tokoh masyarakat terhadap fungsi keluarga Manusia yang membuat tujuan dan manusia pula yang melakukan proses untuk mencapai tujuan. Tanpa ada manusia tidak ada proses kerja, sebab pada dasarnya manusia adalah makhluk kerja. Berdasarkan hasil penelitian Istriyati di Desa Kumpulrejo Kecamatan Argomulyo Kota Salatiga dari hasil penelitian didapatkan bahwa variabel yang berhubungan dengan kemandirian perimenopause adalah peran tokoh masyarakat, peran keluarga dan promosi kesehatan. Dalam pembangunan kesehatan, tokoh masyarakat merupakan bagian dari sumber daya manusia yang sangat penting perannya guna meningkatkan kesadaran yang lebih tinggi pada pelayanan kesehatan yang bersifat promotif dan preventif. Peran tokoh masyarakat merupakan salah satu contoh (role model) dan motivator bagi para perimenopause untuk memanfaatkan Posbindu. Penelitian Pirnadi mengemukakan bahwa ada hubungan yang signifikan antara peran tokoh masyarakat dengan kehadiran perimenopause di Posbindu. Faktor yang mendorong atau memperkuat terjadinya perubahan perilaku sehat pada masyarakat perlu contoh dari tokoh masyarakat, 
keluarga/ teman sebaya dan petugas kesehatan (Kemenkes, 2010). Peran tokoh masyarakat terhadap fungsi keluarga salah satunya adalah memfasilitasi perimenopause melalui kegiatan-kegiatan pemberdayaan, memberikan motivasi kepada perimenopause untuk tetap sehat, mandiri dan sejahtera, mengalihkan pengetahuan, keterampilan dan teknologi yang bersifat vokasional.

Peran tokoh masyarakat lebih banyak yang terlibat adalah kader kesehatan sebagai ujung tombak di bidang kesehatan memiliki andil dalam usaha mengajak perimenopause untuk memanfaatkan Posbindu perimenopause, teori Green mengatakan peran kader merupakan salah satu faktor pendukung yang berperan dalam perilaku kesehatan karena merupakan faktor penyerta yang berperan untuk mempertahankan perilaku kesehatan.

Menurut asumsi peneliti, peran serta tokoh masyarakat dalam suatu usaha mendukung fungsi keluarga dengan cara menumbuhkan semangat dan rasa memiliki terhadap berbagai kegiatan pembangunan masyarakat berdasarkan atas keterlibatannya dalam perencanaan, pelaksanaan dan evaluasi pembangunan. Peran serta tokoh masyarakat diartikan sebagai bentuk penyerahan sebagian peran dalam kegiatan dan tanggung jawab tertentu yang berasal dari keluarga untuk lingkungannya.

\section{Pengaruh Variabel Peran Tokoh Masyarakat Terhadap Motivasi}

Peran tokoh masyarakat berpengaruh positif terhadap motivasi, hasil uji menunjukkan ada pengaruh positif 0,165729, sedangkan nilai T-Statistic sebesar 2,271652 dan signifikan pada $\alpha=5 \%$. Nilai $T$-Statistic tersebut berada di atas nilai kritis (1,96). Peran tokoh masyarakat berpengaruh positif terhadap motivasi sebesar $11,48 \%$. Dengan demikian hasil penelitian ini ada pengaruh peran tokoh masyarakat terhadap motivasi sehingga parameter peran tokoh masyarakat terhadap motivasi dikatakan signifikan.
Berdasarakan penelitian yang dilakukan oleh Siti untuk mengetahui pengaruh motivasi instrinsik dan ektrinstik terhadap kesiapan mental wanita pra menopouse menghadapi menopouse di Desa Tibang Kecamatan Syiah Kuala Banda Aceh. Dari 45 responden mayoritas kondisi lingkungan ibu tinggal baik 25 orang $(100 \%)$, pada kesiapan mental siap yaitu 19 orang $(76,0 \%)$ dan diharapkan bagi tokoh masyarakat untuk Menjaga kondisi lingkungan tempat ibu tinggal agar ibu lebih siap. Tokoh masyarakat dapat memberikan motivasi yang baik menuju sehat.

Untuk dapat terus berperan dalam lingkungan masyarakat maka wanita perimenopause tetap membutuhkan dukungan dari lingkungan. Pemberian kesempatan dan menjadikan wanita perimenopause sebagai tempat bertanya (sesepuh) dapat menimbulkan perasaan berharga pada dirnya. Mengingat wanita perimenopause perlu mempersiapkan diri dalam memasuki fase yang baru sehingga motivasi serta dukungan sosial diperlukan agar tidak mengalami depresi dalam beradaptasi dengan kondisi baru atau lingkungan baru tersebut. Lingkungan yang paling dekat adalah keluarga seperti pasangan, anak, cucu maupun sahabat dan teman terdekat. Lansia adalah akhir dari penuaan, tahap yang mengalami banyak perubahan baik secara fisik maupun mental. Dengan perubahan fisik wanita perimenopause mengalami penurunan pendengaran dan penglihatan, wanita perimenopause yang sehat secara mental yaitu wanita yang menyenangi aktifitas sehari-hari, punya arti dalam hidup seperti melakukan aktifitas sehari-hari. Peran serta tokoh masyarakat adalah ikut sertanya seluruh anggota dan tokoh masyarakat dalam memecahkan permasalahanpermasalahan masyarakat tersebut. Partisipasi tokoh masyarakat di bidang kesehatan berarti keikut sertaan seluruh anggota masyarakat dalam memecahkan setiap permasalahan. Motivasi merupakan suatu kekuatan penggerak dalam perilaku 
individu baik yang akan menentukan arah maupun daya tahan (perintence) tiap perilaku manusia yang didalamnya terkandung pula unsur-unsur emosional insan yang bersangkutan

Menurut asumsi peneliti, peran tokoh masyarakat untuk menciptakan motivasi dengan dilakukannya penyuluhan dan dukungan yang dibutuhkan lansia agar dapat mandiri, selain itu dapat dilakukan dengan bimbingan dan sebagai penggerak pembangunan kesehatan.

\section{Pengaruh Variabel Peran Tokoh Masyarakat Terhadap Kemandirian Perimenopause}

Peran tokoh masyarakat berpengaruh positif terhadap kemandirian, hasil uji menunjukkan ada pengaruh positif 0,271296, sedangkan nilai T-Statistic sebesar 2,946731 dan signifikan pada $\alpha=5 \%$. Nilai T-Statistic tersebut berada di atas nilai kritis (1,96). Peran tokoh masyarakat berpengaruh secara langsung terhadap kemandirian. Hasil uji koefisien parameter antara peran tokoh masyarakat terhadap kemandirian didapatkan pengaruh langsung sebesar 20,83\%.Dengan demikian hasil penelitian ini ada pengaruh peran tokoh masyarakat terhadap kemandirian sehingga parameter peran tokoh masyarakat terhadap kemandirian dikatakan signifikan.

Faktor yang dapat mempengaruhi kemandirian perimenopause adalah peran tokoh masyarakat, berdasarkan hasil penelitian Istriyati di Desa Kumpulrejo Kecamatan Argomulyo Kota Salatiga dari hasil penelitian didapatkan bahwa variabel yang berhubungan dengan kemandirian perimenopause adalah peran tokoh masyarakat, peran keluarga dan promosi kesehatan. Dalam pembangunan kesehatan, tokoh masyarakat merupakan bagian dari sumber daya manusia yang sangat penting perannya guna meningkatkan kesadaran yang lebih tinggi pada pelayanan kesehatan yang bersifat promotif dan preventif. Peran tokoh masyarakat merupakan salah satu contoh (role model) dan motivator bagi para perimenopause untuk memanfaatkan Posbindu. Penelitian Pirnadi mengemukakan bahwa ada hubungan yang signifikan antara peran tokoh masyarakat dengan kehadiran perimenopause di Posbindu. Faktor yang mendorong atau memperkuat terjadinya perubahan perilaku sehat pada masyarakat perlu contoh dari tokoh masyarakat, teman sebaya dan petugas kesehatan. Peran peran tokoh masyarakat dalam kemandirian perimenopause salah satunya adalah memfasilitasi perimenopause melalui kegiatan-kegiatan pemberdayaan, memberikan motivasi kepada perimenopause untuk tetap sehat, mandiri dan sejahtera, mengalihkan pengetahuan, keterampilan dan teknologi yang bersifat vokasional. $^{15}$

Peran tokoh masyarakat lebih banyak yang terlibat adalah kader kesehatan sebagai ujung tombak di bidang kesehatan memiliki andil dalam usaha mengajak perimenopause untuk memanfaatkan Posbindu perimenopause, teori Green mengatakan peran kader merupakan salah satu faktor pendukung yang berperan dalam perilaku kesehatan karena merupakan faktor penyerta yang berperan untuk mempertahankan perilaku kesehatan. Teori ini sesuai dengan hasil penelitian yang dilakukan Pujiastuti Syahrir yang berjudul Hubungan Lingkungan sosial dan peran tokoh masyarakat dengan Kemandirian Perimenopause Di Panti Sosial Gau Mabaji Sumatera Tahun 2013, dengan hasil penelitian diperoleh bahwa ada hubungan antara peran tokoh masyarakat dengan Kemandirian perimenopause $(\mathrm{p}=0,012)$.

Menurut asumsi peneliti, peran peran tokoh masyarakat dalam kemandirian perimenopause salah satunya adalah memfasilitasi perimenopause melalui kegiatan-kegiatan pemberdayaan, memberikan motivasi kepada perimenopause untuk tetap sehat, mandiri dan sejahtera, mengalihkan pengetahuan, keterampilan dan teknologi yang bersifat vokasional. Peran tokoh masyarakat lebih banyak yang terlibat adalah kader kesehatan 
sebagai ujung tombak di bidang kesehatan memiliki andil dalam usaha mengajak perimenopause untuk memanfaatkan Posbindu perimenopause.

\section{Pengaruh Variabel Fungsi Keluarga Terhadap Motivasi}

Fungsi keluarga berpengaruh positif terhadap motivasi, hasil uji menunjukkan ada pengaruh positif 0,553586 , sedangkan nilai $T$-Statistic sebesar 7,496141 dan signifikan pada $\alpha=5 \%$. Nilai T-Statistic tersebut berada di atas nilai kritis $(1,96)$. Fungsi keluarga berpengaruh positif terhadap motivasi sebesar $47,12 \%$. Dengan demikian hasil penelitian ini ada pengaruh fungsi keluarga terhadap motivasi sehingga parameter fungsi keluarga terhadap motivasi dikatakan signifikan.

Fungsi Keluarga terdiri dari 4 Fungsi Keluarga yaitu dukungan instrumental, informatif, penghargaan dan emosional. Dari keempat Fungsi Keluarga tersebut yang paling banyak adalah dukungan penghargaan. Dukungan penghargaan berupa pujian dan dorongan akan memotivasi lansia mandiri dalam aktivitas sehari-hari. Dengan adanya dukungan penghargaan lansia merasa diperhatikan, disayangi oleh anggota keluarga yang lain sehingga mengurangi ketergantungan lansia kepada orang lain dalam pemenuhan aktivitas sehari-hari.

Keluarga merupakan support system utama bagi lansia dalam mempertahankan kesehatannya. Peranan keluarga dalam perawatan lansia antara lain perawatn fisik, perawatan psikologis, perawatan sosial dan perawatan spiritual. Perawatan lanjut usia di rumah bertujuan memberikan perawatan sebaik mungkin tanpa mengganggu atau mengurangi kemandirian lanjut usia. Kemandirian dalam melakukan aktivitas sehari-hari harus diupayakan, walaupun dalam beberapa aktivitas tentu perlu dibantu (Nugroho, 2008). Perawatan yang dilakukan anak sendiri diduga memberikan rasa aman dan nyaman karena mereka lebih toleran terhadap lansia dibandingkan kerabat atau orang lain, sehingga kebutuhan fisik, psikis, sosial, ekonomi dan spiritual lansia bisa terpenuhi dengan baik. Pada saat merawat lansia, akan sering timbul konflik pada keluarga yang tinggal bersama atau dekat, sedangkan keluarga yang jauh dirindukan tetapi tidak bisa sering berkunjung. ${ }^{17}$

Menurut asumsi peneliti, keluarga sangat dibutuhkan dukungannya dalam masa pemulihan, terutama mendampingi dalam program fisioterapi maupun pengobatan, serta melakukan aktivitas sehari-hari, termasuk beribadah. Keluarga juga harus menyiapkan lingkungan yang kondusif di rumah serta memperhatikan kesehatan fisik dan emosionalnya sendiri selama merawat lansia, sehingga lansia menjadi mandiri sesuai dengan kemampuannya.

\section{Pengaruh Variabel Fungsi Keluarga Terhadap Kemandirian Perimenopausel}

Fungsi keluarga berpengaruh positif terhadap kemandirian, hasil uji menunjukkan ada pengaruh positif 0,322206, sedangkan nilai T-Statistic sebesar 3,379271 dan signifikan pada $\alpha=5 \%$. Nilai $T$-Statistic tersebut berada di atas nilai kritis $(1,96)$. Fungsi keluarga berpengaruh secara langsung dan tidak langsung terhadap kemandirian. Hasil uji koefisien parameter antara fungsi keluarga terhadap kemandirian didapatkan pengaruh langsung sebesar 26,94. Dengan demikian hasil penelitian ini ada pengaruh fungsi keluarga terhadap kemandirian. Sehingga parameter fungsi keluarga terhadap kemandirian dikatakan signifikan.

Hasil penelitian dengan judul Pengaruh fungsi keluarga Terhadap Kemandirian perimenopause di Puskesmas Tegal Gundil Bogor Utara 2014, bahwa Ada pengaruh langsung dukungan keluarga terhadap kemandirian perimenopause di Puskesmas Tegal Gundil Bogor Utara sebesar 26.7\%. Fungsi keluarga merupakan hal yang penting dalam mewujudkan perimenopause yang sejahtera lahir dan batin. Dukungan lahir dapat diperankan oleh siapa saja, tetapi kebutuhan emosional dan batin memerlukan 
keterlibatkan keluarga mereka secara intensif dan bahkan dapat memperkuat hubungan antar generasi. Keberadaan suatu hubungan diantara dukungan keluarga dengan sikap kemandirian dari perimenopause dengan bantuan dan suatu pendampingan dari keluarga, perimenopause akan mudah melakukan kemandiriannya pada kehidupan keseharian, sebab perimenopause akan merasa diberi perhatian dengan demikian bisa tergapai suatu kemandirian yang baik. Dalam memberikan bantuan pada para perimenopause supaya tetap mampu melakukan aktivitas, diperlukan sebuah dukungan dari keluarga. Fungsi keluarga menjadi sebuah bantuan yang dapat diterima oleh individu dari orang-orang tertentu pada kehidupannya dan ada pada lingkungan sosial tertentu, yang mampu membuat si penerima mempunyai rasa diberikan perhatian, dihargai dan dicintai. $^{18}$

Menurut asumsi peneliti, fungsi keluarga yang diperoleh responden berupa sikap dihormati dan dihargai oleh anggota keluarga, bersikap sabar dan bijaksana terhadap responden, sering menanyakan dan mendengarkan keluhan responden, memberikan motivasi untuk mengikuti kegiatan di luar rumah, memberikan motivasi untuk hidup bersih dan sehat, memberikan dorongan untuk memeriksakan kesehatan secara teratur, diikut sertakan dalam peristiwa penting keluarga. Responden yang tidak mendapat Fungsi Keluarga ini disebabkan oleh beberapa hal: responden dengan status janda/duda yang tinggal sendiri, responden tinggal bersama pasangan dan sudah hidup terpisah dengan anak-anak yang sudah pergi merantau, dan bahkan ada responden yang tinggal berdampingan dengan anak-anak tetapi sudah tidak mendapat perhatian lagi.

\section{Pengaruh Variabel Motivasi Terhadap Kemandirian Perimenopause}

Motivasi wanita perimenopause berpengaruh positif terhadap kemandirian, hasil uji menunjukkan ada pengaruh positif 0,209317, sedangkan nilai T-Statistic sebesar 2,048239 dan signifikan pada $\alpha=5 \%$. Nilai T-Statistic tersebut berada di atas nilai kritis $(1,96)$. Motivasi wanita perimenopause berpengaruh secara langsung terhadap kemandirian. Hasil uji koefisien parameter antara motivasi terhadap kemandirian didapatkan pengaruh langsung sebesar $17,13 \%$. Dengan demikian hasil penelitian ini ada pengaruh motivasi terhadap kemandirian sehingga parameter motivasi terhadap kemandirian dikatakan signifikan.

Penelitian Antari menunjukan ada pengaruh yang positif antara motivasi lansia dengan kemandirian lansia. Dalam melakukan kegiatan, motivasi dapat dikatakan sebagai keseluruhan daya penggerak di dalam diri individu yang menimbulkan rasa melakukan sesuatu, yang menjamin kelangsungan dari kegiatan dan yang memberikan arah pada kegiatan, sehingga tujuan yang dikehendaki oleh individu itu dapat tercapai. Dikatakan "keseluruhan", karena pada umumnya ada beberapa motif yang bersama-sama menggerakkan seseorang untuk bertindak. ${ }^{19}$

Faktor yang juga mempengaruhi kemandirian sosial adalah motivasi perimenopause. Secara umum kondisi fisik seseorang yang telah memasuki masa lanjut usia mengalami penurunan. Hal ini dapat dilihat dari beberapa perubahan. Perubahan penampilan pada bagian wajah, tangan, dan kulit. Perubahan bagian dalam tubuh seperti sistem saraf: otak, isi perut, limpa, hati. Perubahan panca indra seperti penglihatan, pendengaran, penciuman, perasa, dan perubahan motorik antara lain berkurangnya kekuatan, kecepatan dan belajar keterampilan baru. Perubahan-perubahan tersebut pada umumnya mengarah pada kemunduruan kesehatan fisik dan psikis yang akhirnya akan berpengaruh juga pada aktivitas ekonomi dan sosial mereka. Sehingga secara umum akan berpengaruh pada aktivitas kehidupan sehari-hari. Secara Biologi, lanjut usia mengalami proses penuaan secara terus menerus yang ditandai dengan menurunnya daya fisik terhadap penyakit 
Menurut asumsi peneliti, dengan adanya motivasi lansia dapat membantu meningkatkan keyakinan akan kemampuannya melakukan perawatan diri. Hasil penelitian tersebut menjelaskan motivasi merupakan serangkaian usaha untuk menyediakan kondisi-kondisi tertentu, sehingga seseorang mau dan ingin melakukan sesuatu, dan apabila ia tidak suka itu. Jadi, motivasi itu dapat dirangsang oleh faktor dari luar tetapi motivasi itu adalah tumbuh di dalam diri seseorang.

\section{Pengaruh Variabel Tidak Langsung Lingkungan Sosial Terhadap Kemandirian}

Lingkungan sosial berpengaruh secara tidak langsung terhadap kemandirian. Hasil uji koefisien parameter antara lingkungan sosial terhadap kemandirian didapatkan pengaruh tidak langsung antara lingkungan sosial terhadap kemandirian melalui peran tokoh masyarakat, fungsi keluarga dan motivasi didapatkan nilai sebesar $0,72 \%$.

Apabila kebutuhan tersebut bisa terpenuhi, maka timbulah angan-angan untuk berfikir dan berusaha untuk mencapai bagaimana bisa terpenuhi kebutuhan tersebut misalnya makan, pakaian, tempat tinggal dan kesehatan. Wanita perimenopause bukanlah untuk mengembalikan peran mereka sebagai pencari nafkah, melainkan bagaimana mempersiapkan mereka untuk dapat menikmati ruas akhir dari kehidupannya dengan kemandirian yang maksimal. Bila kemandirian menolong diri sendiri tanpa bantuan telah tercapai, maka masih banyak lahan kegiatan untuk para usia wanita menopause yang masih dapat digali dan dimunculkan. Eratnya ikatan kekeluargaan diantara anggota keluarga dan lingkungan sosial disekitarnya, memungkinkan seseorang usia lanjut selalu sibuk. Mulai dari menjaga cucu, mengikuti kegiatan keagamaan, mengembangkan hobi, aktif kegiatan sosial dan rumah tangga hingga usaha berdagang ataupun usaha lain menghasilkan tambahan penghasilan
Menurut asumsi peneliti, pemberian kesempatan dan menjadikan wanita perimenopause sebagai tempat bertanya (sesepuh) dapat menimbulkan perasaan berharga pada dirnya. Mengingat wanita perimenopause perlu mempersiapkan diri dalam memasuki fase yang baru sehingga lingkungan sosial yang baik diperlukan agar tidak mengalami depresi dalam beradaptasi dengan kondisi baru atau lingkungan baru tersebut. Lingkungan disinyalir mempunyai hubungan yang cukup berperan terhadap Kemandirian Perimenopause.

\section{Pengaruh Antar Variabel Tidak Langsung Peran Tokoh Masyarakat Terhadap Kemandirian}

Peran tokoh masyarakat berpengaruh secara tidak langsung terhadap kemandirian. Hasil uji koefisien parameter antara peran tokoh masyarakat terhadap kemandirian didapatkan pengaruh tidak langsung antara peran tokoh masyarakat terhadap kemandirian melalui fungsi keluarga, maupun motivasi didapatkan nilai sebesar $0,44 \%$.

Menurut Purba menyatakan untuk menciptakan clean environmental management and good environmental governance, menuntut persyarat adanya keterbukaan, kesetaraan, partisipasi dan pemberdayaan masyarakat serta akuntabilitas. Lahirnya pembangunan partisipasi khususnya dalam pengelolaan peran serta masyarakat dalam penanggulangan bencana dilatarbelakangi oleh program, proyek dan kegiatan pembangunan yang selama ini dilakukan sering gagal. Peran serta masyarakat dalam penanggulangan bencana yang selama ini dikembangkan dan dipraktekkan cenderung mengarah pada dua pendekatan yang bertolak belakang yakni state-based dan community-based. Model state-based seringkali mengalami kegagalan atau hambatan hal tersebut dikarenakan model tidak fleksibel,lemah dalam kapasistas kelembagaan, kurang tepatnya disain dan implementasi serta kurangnya peran serta masyarakat. $^{20}$ 
Menurut asumsi peneliti, peran peran tokoh masyarakat dalam kemandirian perimenopause salah satunya adalah memfasilitasi perimenopause melalui kegiatan-kegiatan pemberdayaan, memberikan motivasi kepada perimenopause untuk tetap sehat, mandiri dan sejahtera, mengalihkan pengetahuan, keterampilan dan teknologi yang bersifat vokasional. Peran tokoh masyarakat lebih banyak yang terlibat adalah kader kesehatan sebagai ujung tombak di bidang kesehatan memiliki andil dalam usaha mengajak perimenopause untuk memanfaatkan Posbindu perimenopause.

\section{Pengaruh Antar Variabel Tidak Langsung Fungsi Keluarga Terhadap Kemandirian}

Fungsi keluarga berpengaruh secara tidak langsung terhadap kemandirian.Hasil uji koefisien parameter antara fungsi keluarga terhadap kemandirian didapatkan pengaruh tidak langsung antara fungsi keluarga terhadap kemandirian melalui motivasi didapatkan nilai sebesar 0,29\%

Hal tersebut sejalan dengan hasil beberapa studi yang dirangkum oleh Pickett mengenai pola mortalitas menunjukkan bahwa lansia yang tinggal bersama lebih mungkin untuk bertahan hidup dan mempertahankan kemandirian mereka dibanding mereka yang hidup sendirian. Angka kematian untuk pria lansia secara substansial jauh lebih tinggi dibanding wanita lansia. Hidup menjanda atau menduda mempunyai pengaruh jenis kelamin tertentu, meningkatka angka kematian pria yang ditinggalkan.

Salah satu fungsi keluarga adalah fungsi asih dimana antar anggota keluarga saling memberikan kasih sayang dan rasa aman, memberikan perhatian dan kehangatan terutama pada lansia yang mengalami penurunan kemampuan fisik. Dalam teori kepribadian menyatakan lansia (yang usianya diatas 60 tahun) merasa hidup mereka sudah dekat dengan akhir hayat dan pada masa ini kasih sayang dari lingkup keluarga terdekat merupakan kenikmatan tersendiri. Hal ini menunjukkan bahwa perawatan oleh keluarga akan menguntungkan tidak hanya secara fisik tapi juga psikologis lansia

Keluarga mempunyai empat peran utama dalam membantu Kemandirian Perimenopause, salah satunya adalah motivator yaitu dengan memberikan dukungan secara emosional, yang membuat lansia punya motivasi untuk dapat melakukan aktivitasnya semandiri mungkin. Contohnya, dengan memberikan pujian saat mampu mandi sendiri.

Menurut asumsi peneliti, fungsi keluarga yang diperoleh responden berupa sikap dihormati dan dihargai oleh anggota keluarga, bersikap sabar dan bijaksana terhadap responden, sering menanyakan dan mendengarkan keluhan responden, memberikan motivasi untuk mengikuti kegiatan di luar rumah, memberikan motivasi untuk hidup bersih dan sehat, memberikan dorongan untuk memeriksakan kesehatan secara teratur, diikut sertakan dalam peristiwa penting keluarga. Responden yang tidak mendapat Fungsi Keluarga ini disebabkan oleh beberapa hal: responden dengan status janda/duda yang tinggal sendiri, responden tinggal bersama pasangan dan sudah hidup terpisah dengan anak-anak yang sudah pergi merantau, dan bahkan ada responden yang tinggal berdampingan dengan anak-anak tetapi sudah tidak mendapat perhatian lagi.

\section{Simpulan}

Dari penelitian ini dapat disimpulkan bahwa fungsi keluarga yang paling mempengaruhi kemandirian pada lansia Tahun 2017, dikarenakan fungsi keluarga adalah media pertama lansia dalam bersosialisai. Dimana Keluarga adalah kelompok yang mempunyai peranan yang amat penting dalam mengembangkan, mencegah, mengadaptasi, dan atau memperbaiki masalah kesehatan yang ditemukan dalam keluarga. Masalah kesehatan anggota keluarga amat terkait 
dengan berbagai masalah anggota keluarga lainnya, jika ada salah satu anggota keluarga yang bermasalah kesehatannya pasti akan mempengaruhi fungsi-fungsi keluarga tersebut

\section{Daftar Pustaka}

Kemenkes Ri, Profil Data Kesehatan Indonesia . Jakarta: Kementrian Kesehatan Ri, 2012.

Proverawati, Atikah Keperawatan Lanjut Usia. Yogyakarta : Graha Ilmu. 2010

Bappenas, Statistik Penduduk Lanjut Usia. Jakarta: Badan Pusat Statistik. 2015.

Hawari, D. Menjaga Keseimbangan Kualitas Hidup Para Lanjut Usia, Panduan Gerontologi, Tinjauan Dari Berbagai Aspek. Jakarta: PT. Gramedia Pustaka Utama 2012.

Adriyani, A. Uji Keandalan Dan Kesahihan Indeks Activity Of Daily Living Barthel Untuk Mengukur Status Fungsional Dasar Pada Usia Lanjut Di Rscm. Tesis. Jakarta: Program Studi Ilmu Penyakit Dalam Fakultas Kedokteran Universitas Indonesia 2012.

Rinajumita, Faktor-Faktor Yang Berhubungan Dengan Kemandirian Lansia Di Wilayah Kerja Puskesmas Lampasi Kecamatan Payakumbuh Utara Tahun 2011. Fakultas Kedokteran. Jurusan Program Studi Ilmu Kesehatan Masyarakat Universitas Andalas Padang. 2011.

Darmojo, Geriatri (Ilmu Kesehatan Usia Lanjut).Jakarta: Fkui. 2012.

Hadywinoto, Menjaga Keseimbangan Kualitas Hidup Para Lanjut Usia, Panduan Gerontologi, Tinjauan Dari Berbagai Aspek. Jakarta: Pt. Gramedia Pustaka Utama 2010.

Fatonah, Keperawatan Keluarga: Teori Dan Praktik. Edisi 5. Jakarta: Egc. 2006.

Notoadmodjo, Metodologi Penelitian Kesehatan. Jakarta: Pt Rhineka Cipta. 2010.

Sairin, Pengaruh, Lingkungan sosial, Peran Tokoh Masyarakat Terhadap Kemandirian Lansia Di Wilayah Kerja Puskesmas Darusalam Medan. Jurnal Keperawatan Indonesia Vol 8, 2011

Yosep, Perbedaan Antara Tingkat Kemandirian Lansia Yang Ada Di Keluarga Di Desa Temuroso Dengan Lansia Yang Ada Di Panti Wredha Pucang Gading Semarang. Fakultas Ilmu Keperawatan Dan Kesehatan. Jurusan Program Studi Ilmu Keperawatan Universitas Muhammadiyah Semarang 2009.

Suardiman, Pengaruh Faktor_Faktor Kesehatan, Ekonomi, Dan Hubungan Sosial Terhadap Kemandirian Orang Lanjut Usia. Skripsi. Surabaya: Fakultas Kesehatan Masyarakat Universitas Airlangga. 2011.

Erlinafsiah Gambaran Tingkat Kemandirian Dalam Activity Of Daily Living Dan Resiko Jatuh Pada Lansia Di Panti Sosial Tresna Wredha Budi
Mulia 01 Dan 03 Jakarta Timur. Fakultas Ilmu Keperawatan Universitas Indonesia.2010

Istriyati. Pengaruh Peran Tokoh Masyarakat Yang Dapat Mempengaruhi Kemandirian Perimenopause. Jurnal Kesehatan Masyarakat. Universitas Airlangga 2012

Siti Julita, Motivasi Instrinsik Dan Ektrinstik Terhadap Kesiapan Mental Wanita Pra Menopouse Menghadapi Menopouse Di Desa Tibang Kecamatan Syiah Kuala Banda Aceh. Jurnal Keperawatan Universitas Indonesia 2010

Nugroho, Pengaruh Lingkungan Keluarga, Motivasi Terhadap Kualitas Hidup Lansia. Jurnal Kesehatan Masyarakat. Universitas Indonesia. 2008.

Kiki Novianty The Social Foundations Of Religious Meaning In Life Research On Aging. The Journals Of Gerontology . 30, 395427. 2014

Antari, Rasdini Dan Triyani. Pengaruh Yang Positif Antara Motivasi Lansia Dengan Kemandirian Lansia. Jurnal Universitas Negri Padang 2011

Purba, Faktor-Faktor Yang Berhubungan Dengan Pemanfaatan Posyandu Lansia Di Desa Jetis Kecamatan Karangrayung Kabupaten Grobogan. Tesis. Semarang: Program Studi Magister Promosi Kesehatan Program Pascasarjana Universitas Diponegoro 2012.

Pickett Pemanfaatnan Pos Pelayanan Terpadu Di Perumahan Pondok Cilegon Indah. Tangerang: Program Studi Kesehatan Masyarakat, Stikes Faletehan. Banten 2009 